\title{
Effectiveness of a Training Program in Improving Study Skills and English Language Achievement among High School Students
}

\author{
Maysoon A. Dakhiel (Corresponding author) \\ Assistant Professor of Curriculum and Instruction of English Language \\ Faculty of Education, Jeddah University, Jeddah, Saudi Arabia \\ E-mail:mdkheel@uj.edu.sa \\ Somaya A. Ahmed \\ Associate Professor of Educational Psychology \\ Faculty of Social Sciences, Jeddah University, Jeddah, Saudi Arabia \\ E-mail: sahmed2@uj.edu.sa
}

Received: March 18, 2019 Accepted: May 17, 2019 Published: May 23, 2019

doi:10.5296/jei.v5i1.14685 URL: https://doi.org/10.5296/jei.v5i1.14685

\begin{abstract}
The current study aimed to identify the effectiveness of a training program in the development of study skills and improvement of English language achievement among the $10^{\text {th }}$ grade students. To achieve the study objectives, a training program was designed and applied to (35) first-grade high school students. The respondents were pre- and post- tested by a list of study skills and English language achievement test. The results showed statistically significant differences in favor of the posttest of study skills and English language achievement, suggesting the effectiveness of the utilized training program. The study recommended the need to train teachers on designing the educational tasks of English language course based on study skills.
\end{abstract}

Keywords: Training program, Study skills, English language, Achievement

\section{Introduction}

Academic achievement is one of the topics that have received tremendous attention from educators and psychologists, especially in the current era that witnesses great scientific and 
technical developments in all life fields. Researchers have focused on the role of mental factors in predicting academic success. Moreover, several efforts have been made to associate academic achievement with the following variables: intelligence, motivation for achievement, learning patterns, learning habits, attitudes towards study, personality traits, and study skills.

Theoretical studies and frameworks comprise various concepts of study skills, such as learning how to learn, knowing how to know, knowing how to remember, mental skills training, mnemonic strategies, cognitive elaboration strategies (Rizk, 2004).

Study skills are the learned behavioral patterns employed by the learner in the academic achievement of various courses. They are also the constant accumulation of information. Building the individual cognitively as well as mentally requires the use of appropriate strategies of self-management, time management, and goals setting. Study skills, which involve the above-mentioned aspects, help the learner succeed not only in study, but throughout life, as well (Al-Mokren, 2004).

Al-Amr and Al-Shafei (2007) defined study skills as the methods and approaches followed by the student to acquire distinct information and skills, which reveal the constancy of the student's success in study. They also indicate an individual activity, behavioral patterns and processes carried out by the learner, with or without the faculty supervision, to acquire knowledge or skill. They involve what the person acquires through practice and life experience, as well. Learning comprises behaviors and procedures that influence how the learner can handle information and learn various tasks. Learning is strategic as long as learners are aware of the skills, strategies and methods used in learning as well as their ability to develop them (Al-Abodi, 2014).

Good skills and methods of study are pivotal for improving academic achievement. Results of several Arabic and foreign studies indicated the importance of good study skills in addressing the problem of forgetfulness, information retention in memory, reducing test anxiety, as well as increasing self-confidence and positive attitude towards different courses (Abo-Azab, 2008).

Suliman (1988), Fatim (1989), Zidan and Ibrahim (1990), Nabih (1990), Al-Sheikh and Abd Alrhaheem (1993), Jegede et al. (1997), Al-Shennawi (1998), Musch and Broder (1999), Essa (2000), Al-Khalifi (2000), Al-Ajami (2003), Lin and Mckeachie (2003), Sirohi (2004), Hussein (2007), Al-Amr and Ibrahim (2007), Abd Almajeed (2007), Abu Hashim (2009), and Huang (2018) showed statistically significant correlation between study skills and academic achievement among the students throughout the different educational stages.

Ickes and Fraas (1990), Oakerson (1993), Fredrick (1998), Hacker (1999), Chan et al. (1999), Bender (2001), Raaheim (2003), Sedat (2006), Ghoneim (2005), Al-Amr and Ibrahim (2007), Ghanimat and Alimat (2012), Turkistani (2015), Wernersbach (2011) and Al-Shlawi (2016) revealed a statistically significant effect of study skills-based programs on various courses achievement.

Few studies aimed to identify the relationship between study skills and English language achievement. The authors found no studies addressing training programs that develop study 
skills and improve English language achievement.

Oluwatimilehin and Owoyele (2012) aimed to investigate the relationship between study habits and students' academic achievement in core subjects (i.e., English language, mathematics, science and arts) at the Nigerian junior high schools. Study habits involved assignments, time management, textbook, note taking, procedures of the study period, concentration, written work, tests, teacher consultation and students' achievement. The study was applied to (300) high school students. Results revealed that teacher consultation was the most effective, while time allocation, concentration, no reading and assignments affected the academic performances less. Therefore, regular counseling services relevant to teaching students how to utilize study skills were recommended to reinforce their study habits and academic achievement.

Al-Sabbah (2016) aimed to identify the study habits used by the $2^{\text {nd }}$ grade students in English language at the Community College of Qatar (CCQ) as well as the differences among the participants in the achievement of reading, writing and grammatical rules kills. A six-item questionnaire (place of study, how to study, study time, concentration, memory, management and procrastination) was designed and applied to (50) students. In addition, anxiety test was conducted. Results showed that most prevalent habits among students were: readiness to study (using pencils, pen, lights, notepad, and books), handling difficult subjects when the mind is ready, highlighting the most important ideas, finishing study on time, commencing with teachers' notes, and former predicting of the questions. Furthermore, there were statistically significant differences in the participants' achievement because of the concentration habits and memory in favor of the high achievers.

Study program is beneficial because it is designed to involve the whole courses and help the learner gain knowledge, identify views as well as procedures, explain the phenomena, solve the problems, and create new ideas. Accordingly, the learner can develop and use skills professionally and innovatively and acquire new behaviors beneficial in various spheres of life and academia alike (Wafi, 2010).

According to the new curriculum document published in 2001, the general objectives of teaching English in Saudi Arabia is enabling the students to: develop their intellectual, personal and professional abilities; acquire basic language skills in order to communicate with the speakers of English Language; acquire the linguistic competence necessarily required for various life situations; acquire the linguistic competence required for different professions; develop their awareness of the importance of English as a means of international communication; develop positive attitudes towards learning English; develop the linguistic competence that enables them to be aware of the cultural, economic and social issues of their society in order to contribute to giving solutions; develop the linguistic competence that enables them, in the future; present and explain the Islamic concepts and issues and participate in spreading Islam; develop the linguistic competence that enables them, in the future, to present the culture and civilization of their nation; benefit from English-speaking nations in order to enhance the concepts of international cooperation that develop understanding and respect of cultural differences among nations; acquire the linguistic bases 
that enable them to participate in transferring the scientific and technological advances of other nations to their nation (Al-Hajailan, 2005 in Elyas \& Badawood, 2016).

\subsection{Statement of the Problem}

Although teaching English begins at the sixth primary grade and gets more concern in Saudi Arabia, high school graduates can neither speak fluently nor write accurately (Alrabai, 2014).

Similarly, Rahman and Alhaisoni (2013) argued that Saudi students did not show proficiency in English language which they had learned for several years. Khan (2011) stated that despite the equipment, planning, curriculum, integrated textbooks and qualified teachers, achievement is less than expected and students, at public schools, suffer from low achievement in English language.

Al-Nasser (2015) asserted that although students of public schools studied English for nine years, they could neither speak fluently nor write accurately after graduation.

Mitchel and Alfuraih (2017) addressed the history of English language instruction in Saudi Arabia and applied the study to (500) teachers, teaching from $4^{\text {th }}$ to $12^{\text {th }}$ grades, out of $(35,000)$. Results indicated that only $40 \%$ could pass the exams of English course because they neither did the assignments nor prepared the lesson despite their motivation and the teachers' utilization of modern technology. The classes also were insufficient to practice language skills. $80 \%$ of the respondents reported that the use of Arabic language in the classroom surpassed $30 \%$ because of the pupils' low level.

The authors' view is consistent with the results of the previous studies. Teaching English language over twenty years at the university made them realize that students' level in English is low, not only in vocabulary, but in speaking and writing, as well. Academic achievement in English language is low because students lack the proper study skills, so it is essential to identify the effectiveness of a training program in the development of study skills and improvement of English language achievement among high school students. The present study is consistent with the current approach of the psychological and educational papers, which attempt to redefine the factors affecting academic achievement.

The problem of the present study can be defined in the following major question:

What is the effectiveness of a training program in improving study skills and English language achievement among first-grade high school students?

This major question can be sub-divided into two minor ones:

(1) What is the effectiveness of the utilized program in improving study skills among first-grade high school students?

(2) What is the effectiveness of the utilized program in improving English language achievement among first-grade high school students?

\subsection{Objectives}

The present study aims to identify the following points: 
(1) The effectiveness of a training program in improving study skills among first-grade high school students?

(2) The effectiveness of a training program in improving English language achievement among first-grade high school students?

\subsection{Significance}

The significance of the present study lies in the following points:

(1) Addressing the variable of study skills which tremendously affects achievement, and the completion of the required tasks.

(2) Arabization of study skills scale and verification of the indices of validity and reliability in Saudi Arabia.

(3) Preparing study skills-based training program.

(4) Preparing English language achievement test for the first-grade high school students.

(5) Lack of the studies investigating the impact of training programs on English language achievement in the light of the authors' knowledge of the Arabic and foreign databases.

(6) The results of the present study benefit educators, in general, and teachers, in particular, through developing curricula and teaching methods to motivate the students to use the most effective study skills that improve achievement.

\subsection{Concepts}

\subsubsection{Training Program}

It is procedurally defined as a number of theoretical and practical experiences as well as activities prepared according to the study skills. It involves (14) sessions (two sessions per week throughout 7 weeks), and each session lasts for 40 minutes in order to develop the study skills and improve English language achievement among the first-grade high school students.

\subsubsection{Study Skills}

The study skills in the present study are classified into five independent sub-skills according to the list developed by Dennis (2010). According to this list, they are procedurally defined as the grades in each skill (i.e., the skill of textbook, memory, test preparation, concentration, and time management). They are defined as follows:

\section{(1) Textbook Skill}

It is procedurally defined as the student's ability to formulate questions from a chapter before and after reading, get the meaning of new terms, look for the main ideas, identify clarifying details under each main idea, take notes while reading textbook assignments, review the notes before going on to something else, and compare notes with one or more classmates. 
(2) Memory Skill

It is procedurally defined as the student's ability to use visuals in notes taking, such as sketches, mind maps, diagrams, and charts; organize main ideas and details into some logical or meaningful order; understand material in her notes as opposed to memorizing; create quizzes; and think about material that could be on exams and quizzes.

\section{(3) Test Preparation Skill}

It is procedurally defined as the student's preparation for the test since the beginning of the academic year, turning in all homework assignments on time, getting help from classmates, taking a learning skills class or attending learning skills workshops to learn new skill, doing exercise, and eating well-balanced meals.

\section{(4) Concentration Skill}

It is procedurally defined as the student's ability to pay attention and concentrate through preparing himself/herself for study, study where it is quiet, have all the study equipment handy in the study place (pens, paper, calculator, etc.), study for a length of time then taking a short break before returning to studying, set definite goals, break larger tasks into smaller segments in order to complete a large assignment, and find ways to learn the subject matter when it is not naturally interesting.

(5) Time Management Skill

It is procedurally defined as the student's ability to write out short-term and long-term academic goals, start papers; extra-curricular activities and projects way before they are due, as well as regularly study.

\subsection{Academic Achievement}

It is procedurally defined as the total score of the first-grade high school students in English language achievement test at the end of the second semester in the academic year 2017/2018.

\subsection{Limitations}

The present study is limited to:

Variables: Training program (independent variable); study skills and academic achievement (dependent variable).

Sample: the first-grade students from a high school in Jeddah.

Temporal: The second semester in the academic year 2017/2018.

\subsection{Hypotheses}

(1) There are statistically significant differences between the average scores of the respondents in the pre and posttest for the scale of study skills in favor of the posttest. 


\section{Macrothink}

(2) There are statistically significant differences between the average scores of the respondents in the pre and posttest for the scale of English language achievement in favor of the posttest.

\section{Methodology}

The present study adopts the quasi-experimental method and Pre-Posttest of nonequivalent control group design.

\subsection{Sample}

The sample consisted of (35) first-grade high school students with a mean age of (17.2 year) and a standard deviation of (1.4). The respondents' scores were used to verify the hypotheses validity.

\subsection{Tools}

\subsubsection{Training Program}

The content was selected from the books and references of educational psychology as well as teaching methods and strategies. The program also involved a number of educational activities related to the content of the sub-skill in order to reinforce the student's comprehension of the educational material of the study skill. The following fundamentals were taken into account when defining teaching and learning activities:

$\checkmark$ They should associate with the objectives, content and teaching methods of English language.

$\checkmark$ They should allow the participants positive and effective participation.

$\checkmark$ They should provide the participants with feedback that helps them promote their educational level.

The program comprised (14) sessions and the session lasted for a class: Students' preparation ( 5 minutes), delivering the objectives (5 minutes), content ( 25 minutes), and assessment (10 minutes).

(1) Validity

The program's first draft was reviewed by (5) reviewers specialized in Psychology and English Language teaching methods in Jeddah University in order to evaluate the instructions validity and appropriateness for the students, consistency of the educational objectives of the session, integrity and formulation of the content to accomplish the goals of each session, and the activities' consistency with the content. The adjustments, suggested by the reviewers, were conducted.

\section{(2) Application}

Before implementing the program, English language achievement test and study skills inventory were pre-applied to the sample. The program started with defining its objectives, the concept of study skills and the importance of its application in English language. It 
involved the students' application of the sessions content through a number of individual and group activities. The method of lecture, discussion and cooperative learning was used. The students were asked to practice the skills they trained on through the assignments defined at the end of the session. There was a discussion of the assignments at the beginning of the session to determine their commitment to practice what was learned in the session and to identify their difficulties. After the completion of the program, the achievement test and study skills inventory were post-applied to the participants.

\subsubsection{Study Skills Inventory}

After reviewing various foreign and Arabic questionnaires, inventories and scales, the study skills inventory developed by Ahmed (2015) was adopted. It consisted of (51) items; divided into (5) sub-skills: (13) textbook, (9) memory, (13) test preparation, (9) concentration (7) time management. The participants circled the number $(1,2,3,4$, or 5$)$ of the following five answers: always, very frequently, occasionally, rarely, and never that describe the student's behavior in the particular study skill. Every number was handled as an independent variable. Table (1) shows the distribution of the items of the study skills inventory.

Table 1. Distribution of the items of the study skills inventory

\begin{tabular}{|l|l|}
\hline Skill & Items \\
\hline Textbook & $1-13$ \\
\hline Memory & $14-22$ \\
\hline Test preparation & $23-35$ \\
\hline Concentration & $36-44$ \\
\hline Time management & $45-51$ \\
\hline
\end{tabular}

To verify the inventory's psychometric characteristics in Saudi Arabia, it was applied to (100) students and the following procedures were conducted.

(1) Validity

(a) Factor Validity: The inventory's factor validity was verified using Confirmatory Factor Analysis ( CFA) of Maximum Likelihood which indicted that all sub-skills involved one factor (1.89), representing (37.79\%) of the total variance. Chi square was (6.65), freedom degree was (5\%), significant level rated (0.24) and proportion of Chi square was (1.33). Accordingly, data was consistent with the proposed model of the five sub-skills, whose loadings were $(0.784,0.531,0.736,0.348,0.575)$.

(b) Criterion-related Validity: The validity of criterion was verified by the application of study skills inventory (prepared by Abu Hashim, 2008) to the pilot sample and measuring the correlation coefficients between the students' scores in the present inventory and the total 
score of the scale as shown in Table 2.

Table 2. Correlation coefficients of study skills inventory with the scale

\begin{tabular}{|l|l|}
\hline Skill & Correlation Coefficient \\
\hline Textbook & $0.597 * *$ \\
\hline Memory & $0.530 * *$ \\
\hline Test preparation & $0.462 * *$ \\
\hline Concentration & $0.563 * *$ \\
\hline Time management & $0.499 * *$ \\
\hline
\end{tabular}

Table 2 reveals that the values of the correlation coefficients of the scale are statistically significant at the level of (0.01) suggesting that the high validity of the inventory.

(2) Reliability

(a) Internal Validity: the scale internal validity was verified by measuring the correlation coefficients between pilot sample's scores in each item and the total score of the sub-skill. All the values of the correlation coefficients ranged from $(0.300)$ to $(0.671)$ and were significant the level of (0.01), as shown in Table 3 . 
Table 3. Correlation coefficients between the items and the total score of each skill

\begin{tabular}{|c|c|c|c|c|c|c|c|c|}
\hline Skill & No. & $\begin{array}{l}\text { Correlation } \\
\text { coefficient }\end{array}$ & Skill & No. & $\begin{array}{l}\text { Correlation } \\
\text { coefficient }\end{array}$ & Skill & No. & $\begin{array}{l}\text { Correlation } \\
\text { coefficient }\end{array}$ \\
\hline \multirow{13}{*}{ 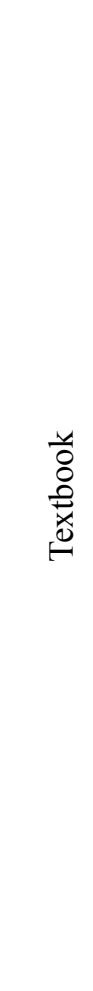 } & 1 & $0.327 * *$ & & 18 & $0.540 * *$ & & 35 & $0.555^{* *}$ \\
\hline & 2 & $0.443 * *$ & & 19 & $0.606 * *$ & \multirow{9}{*}{ 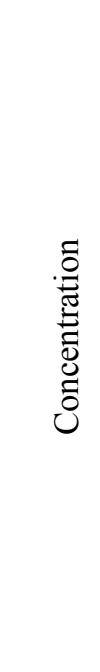 } & 36 & $0.451 * *$ \\
\hline & 3 & $0.530 * *$ & & 20 & $0.590 * *$ & & 37 & $0.457 * *$ \\
\hline & 4 & $0.574 * *$ & & 21 & $0.469 * *$ & & 38 & $0.533 * *$ \\
\hline & 5 & $0.528 * *$ & & 22 & $0.558 * *$ & & 39 & $0.420 * *$ \\
\hline & 6 & $0.546 * *$ & \multirow{12}{*}{ 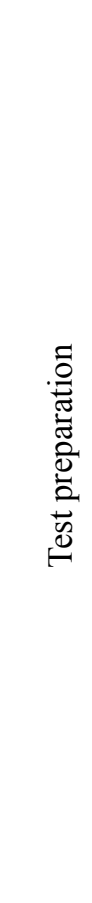 } & 23 & $0.330 * *$ & & 40 & $0.405 * *$ \\
\hline & 7 & $0.479^{* *}$ & & 24 & $0.360 * *$ & & 41 & $0.385 * *$ \\
\hline & 8 & $0.611 * *$ & & 25 & $0.460 * *$ & & 42 & $0.308 * *$ \\
\hline & 9 & $0.753 * *$ & & 26 & $0.376 * *$ & & 43 & $0.267 * *$ \\
\hline & 10 & $0.734 * *$ & & 27 & $0.369^{* *}$ & & 44 & $0.549 * *$ \\
\hline & 11 & $0.633 * *$ & & 28 & $0.759 * *$ & \multirow{7}{*}{ 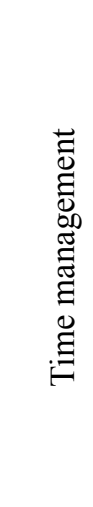 } & 45 & $0.478 * *$ \\
\hline & 12 & $0.504 * *$ & & 29 & $0.665 * *$ & & 46 & $0.560 *$ \\
\hline & 13 & $0.371 * *$ & & 30 & $0.594 * *$ & & 47 & $0.704 * *$ \\
\hline \multirow{4}{*}{ 롱 } & 14 & $0.500 * *$ & & 31 & $0.446 * *$ & & 48 & 0 . Right \\
\hline & 15 & $0.465 * *$ & & 32 & $0.495 * *$ & & 49 & $0.576 * *$ \\
\hline & 16 & $0.652 * *$ & & 33 & 0. line $* *$ & & 50 & $0.506 * *$ \\
\hline & 17 & $0.650 * *$ & & 34 & $0.473 * *$ & & 51 & $0.491 * *$ \\
\hline
\end{tabular}

Note. ${ }^{* *}$ Significant at the level of (0.01).

Table 3 indicates that all values of correlation coefficient are statistically significant at the level of (0.01), ranging from (0.267) to (0.778). Correlation coefficients between sub-skills and the total score of the inventory were statistically significant at the level of (0.01), rating $(0.653,0.471,0.803,0.660,0.835)$, respectively.

(b) Cronbach's Alpha $(\alpha)$ : Reliability of the different sub-skills was estimated through calculating the value of Cronbach's alpha $(\alpha)$ for each skill separately. High values of reliability coefficients for the five sub-skills are shown in Table 4. 
Table 4. Values of reliability coefficients for the study skills inventory

\begin{tabular}{|l|l|}
\hline Skill & Cronbach's Alpha $(\alpha)$ \\
\hline Textbook & 0.795 \\
\hline Memory & 0.726 \\
\hline Test preparation & 0.713 \\
\hline Concentration & 0.609 \\
\hline Time management & 0.634 \\
\hline
\end{tabular}

Table 4 shows that all the values of Cronbach's alpha $(\alpha)$ are high and rating from $(0.609)$ to $(0.866)$, so the inventory is highly reliable. The above-mentioned procedures suggest that the inventory is applicable to the participants.

\subsubsection{English Language Achievement Test}

For achieving the study objectives, Dakhiel, the first author of the current paper, prepared an English language achievement test for the $10^{\text {th }}$ grade students in the first semester of the academic year 2017/2018. It consisted of (60) questions that measure the level of cognitive learning outcomes of knowledge, understanding, application, analysis, composition, and evaluation. The test questions were distributed according to the relative weight of the subjects calculated by the number of classes $(\mathrm{N}=12)$. Then, the relative weights of the cognitive learning outcomes of each subject were distributed, as they ranged from one subject to another.

(1) Reviewers' Validity

The test first draft was reviewed by (10) English teachers at high school and (2) faculty members specialized in English Language teaching methods at the Faculty of Education (Jeddah University) in order to evaluate wordiness as well as clarity of the questions and inclusion of the book content, suggest any changes of the questions, and delete the inappropriate ones. Accordingly, the test was modified to comprise (40) questions.

(2) Easiness, Difficulty and Discrimination Coefficient of the Achievement Test Items

After applying the achievement test to the pilot sample, the items psychometric characteristics of easiness, difficulty and discrimination coefficients were defined. Consequently, the questions, whose difficulty coefficients ranged from $(0.40)$ to $(0.60)$, were kept; and the values of discrimination coefficients ranged from $(0.21)$ to $(0.55)$. Because the values were acceptable, the test final draft involved (40) question.

(3) Validity

Concurrent validity was estimated through finding the values of correlation between the pilot sample's scores in the achievement test and their final scores in English language at the end 
of the intermediate stage. Value of correlation coefficient was $(0.77)$, and significant at the level of (0.01).

(4) Reliability

Test reliability was estimated using Cronbach's alpha $(\alpha)$. Values of reliability coefficient rated (0.85), suggesting that the test was highly reliable. The above-mentioned procedures suggest that the achievement test is applicable to the participants.

\section{Results and Discussion}

\subsection{Results of the First Hypothesis}

To verify the first hypothesis, stating that: There are statistically significant differences between the average scores of the respondents in the pre and posttest for the scale of study skills in favor of the posttest, Paired-Samples T-Test applied to get the differences in the participants' average scores in the pre and posttest of the investigated study skills. Table (5) shows results of the first hypothesis.

Table 5. T-Test results of the differences in the participants' average scores in the pre and posttest of the study skills

\begin{tabular}{|c|c|c|c|c|c|c|}
\hline Study skills & Test & No. & $\begin{array}{l}\text { Arithmetic } \\
\text { mean }\end{array}$ & $\begin{array}{l}\text { Standard } \\
\text { deviation }\end{array}$ & $\begin{array}{l}\text { Freedom } \\
\text { degree }\end{array}$ & $\begin{array}{l}\text { T-value \& } \\
\text { significance }\end{array}$ \\
\hline \multirow{2}{*}{ Textbook } & Pretest & 35 & 27.97 & 4.13 & \multirow{2}{*}{34} & \multirow{2}{*}{$8.08 * *$} \\
\hline & Posttest & 35 & 33.14 & 3.07 & & \\
\hline \multirow{2}{*}{ Memory } & Pretest & 35 & 16.40 & 6.53 & \multirow{2}{*}{34} & \multirow{2}{*}{$12.65^{* *}$} \\
\hline & Posttest & 35 & 33.14 & 3.07 & & \\
\hline \multirow{2}{*}{ Test preparation } & Pretest & 35 & 24.22 & 5.20 & \multirow{2}{*}{34} & \multirow{2}{*}{$19.56^{* *}$} \\
\hline & Posttest & 35 & 49.74 & 5.81 & & \\
\hline \multirow{2}{*}{ Concentration } & Pretest & 35 & 22.22 & 6.63 & \multirow{2}{*}{34} & \multirow{2}{*}{$12.68 * *$} \\
\hline & Posttest & 35 & 47.45 & 10.65 & & \\
\hline \multirow{2}{*}{ Time management } & Pretest & 35 & 14.68 & 4.03 & \multirow{2}{*}{34} & \multirow{2}{*}{$16.67 * *$} \\
\hline & Posttest & 35 & 28.57 & 4.16 & & \\
\hline
\end{tabular}

Note. ** Statistically significant at the level of (0.01).

Table 5 shows that there are statistically significant differences in the participants' average scores in the pre and posttest of study skills in favor of the posttest. The results show the effectiveness of the program in the development of study skills among the participants. 


\subsection{Results of the Second Hypothesis}

To verify the second hypothesis, stating that: There are statistically significant differences between the average scores of the respondents in the pre and posttest for the scale of English language achievement in favor of the posttest, Paired-Samples T-Test applied to get the differences in the participants' average scores in the pre and posttest of English language achievement. Table 6 shows results of the second hypothesis.

Table 6. T-Test results of the differences in the participants' average scores in the pre and posttest of English language achievement

\begin{tabular}{|l|l|l|l|l|l|l|}
\hline Variable & Test & No. & $\begin{array}{l}\text { Arithmetic } \\
\text { mean }\end{array}$ & $\begin{array}{l}\text { Standard } \\
\text { deviation }\end{array}$ & $\begin{array}{l}\text { Freedom } \\
\text { degree }\end{array}$ & $\begin{array}{l}\text { T-value \& } \\
\text { significance }\end{array}$ \\
\hline \multirow{2}{*}{ Academic achievement } & Pretest & 35 & 17.54 & 3.18 & \multirow{2}{*}{34} & $10.031^{* *}$ \\
\cline { 2 - 6 } & Posttest & 35 & 27.91 & .538 & \\
\hline
\end{tabular}

Note. ** Statistically significant at the level of (0.01).

Table 6 shows that there are statistically significant differences in the participants' average scores in the pre and posttest of the study skills in favor of the posttest. The results show the effectiveness of the program in the development of English language achievement among the participants.

That result is consistent with Ickes and Fraas (1990); Oakerson (1993); Fredrick (1998); Hacker (1999); Chan et al. (1999); Bender (2001); Raaheim (2003); Sedat (2006); Ghoneim (2005); Al-Amr and Ibrahim (2007); Ghanimat and Alimat (2012); and Turkistani (2015) who showed a statistically significant effect of study skills training on academic achievement.

It is also consistent with Suliman (1988), Fatim (1989), Zidan and Ibrahim (1990), Nabih (1990), Al-Sheikh and Abd Alrhaheem (1993), Jegede et al. (1997), Al-Shennawi (1998), Musch and Broder (1999), Essa (2000), Al-Khalifi (2000), Al-Ajami (2003), Lin and Mckeachie (2003), Sirohi (2004), Hussein (2007), Al-Amr and Ibrahim (2007), Abd Almajeed (2007), Abu Hashim (2009), and Zhuang (2018) that revealed a statistically significant correlation between study skills and academic achievement among the students throughout the different educational stages.

\section{Discussion}

The results indicate the effectiveness of the training program in improving study skills and English language achievement among first-grade high school students $\left(10^{\text {th }}\right.$ grade). This effectiveness is relevant to the fact that training on good study skills is an effective method to develop them and to improve academic achievement among the participants because of the strong association between the improvement of good study skills and academic achievement. It is a logical result because the study skills, on which the student has trained, have become a 
part in the study and learning process. Accordingly, the student will be able to ask and answer questions from before and after reading a given subject. The student also can get the meaning of new concepts, look for the main ideas, identify clarifying details under each main idea, take notes while reading textbook assignments, review notes and compare them with other classmates, in addition to using visuals in notes taking, such as sketches, mind maps, diagrams and charts. Acquisition of good study skills enables the student to organize main ideas and details into some logically meaningful order and understand material as opposed to memorizing. It also helps the student prepare for the examination since the beginning of the academic year, do homework and assignments on time, get help from classmates, attend study skills classes and workshops, do exercise, eat well-balanced meals, pay attention and concentrate during study. The student also learns to study, where it is quiet and all the study equipment handy (pens, paper, calculator, etc.).

Moreover, acquisition of good study skills enables the student to organize study time by setting a timetable that includes break sessions. The student can also set definite goals, break larger tasks into smaller ones in order to complete a large assignment, find ways to learn the subject matter when it is not naturally interesting, write out short-term and long-term academic goals, start papers, extra-curricular activities and projects before they are due, as well as study regularly.

In addition, the student will enjoy the learned study skills as they help develop self-confidence, self-management and accomplishment of tasks. To sum up, study skills represent the proper approach to build the student cognitive thinking and to teach him/ her self-management, time management, and goal setting.

This result is consistent with Okasha (1999) concluding that academic achievement is the outcome of a set of dynamic factors, including the environmental effects, the mental cognitive factors, as well as the factors relevant to the learner, such as abilities, readiness, mental and health characteristics, psychological security and experience.

It is also consistent with Zidan and Ibrahim (1990) assuring that the level of academic achievement is influenced by the study skills and habits. Educational psychologists agree that study skills are important variables for good learning. One of the most important factors in learning is the mastery of study skills. Accordingly, the learner will not only succeed at school, but he/she will have the ability to be successful in self-learning through these effective practices of feedback that help achieve the study and learning objectives.

\section{Recommendations}

(1) Training teachers at public schools on utilizing study skills in teaching because of their positive effects on the development of students' skills.

(2) Training teachers at public schools on designing educational tasks of English language course based on study skills.

(3) Raising students' awareness of the importance of using proper study skills from the basic stages of education and delivering them relevant training. 
(4) Inclusion of study skills course within teacher preparation programs to develop these skills among their students in the future.

\section{References}

Abd Almajeed, A. O. (2007). Study habits and their relationship with achievement among students of the College of Education. Psychological Studies Journal, 4, 45-85.

Abo-Azab, N. I. (2008). Effectiveness of a proposed advising program to reduce examination anxiety among secondary school students in Gaza Governorates (Unpublished MA thesis, Islamic University, Faculty of Education, Palestine).

Abu Hashim, A. M. (2009). Constructive predictive model of study skills, test wisdom and achievement among high stage students. Faculty of Education Journal, 1(68), 211-272.

Ahmed, S. A. (2015). The relative contribution of study skills, academic self-efficacy, and the five major factors of personality in predicting acdemic achievement among the preparatory year students. Journal of Educational Sciences, 23(4), 399-453.

Al-Abodi, F. (2014). Strategies for Learning, Teaching and Evaluation: Project for Establishing Quality and Eligibility for Institutional and Program Accreditation. Deanship of Quality Assurance and Academic Accreditation, Princess Nourah Bint Abdulrahman University, Kingdom of Saudi Arabia.

Al-Ajami, M. M. (2003). Study habits and attitudes towards study and their relationship with educational courses achievement among Faculty of Education Students. The Arab Gulf Journal, 89, 314-349.

Al-Amr, M., \& Ibrahim, A. I. (2007). Study of some characteristics associated with study habits and achievement and the effect of a proposed counseling program on them among Teachers college students in Saudi Arabia. The Egyptian Journal of Psychological Studies, $17(54), 5-47$.

Al-Khalifi, S. Y. (2000). Learning skills and cognitive motivation relation to achievement in a sample of students at College of Education, Qatar University. Journal of Educational Research Center, 9(17), 43-13.

Al-Mokren, A. Y. (2004). Study habits. Guidance and Counseling Center, King Fahd University of Petroleum and Minerals.

Al-Nasser, A. S. (2015). Problems of English Language Acquisition in Saudi Arabia: An Exploratory-cum-remedial Study. Theory and Practice in Language Studies, 5(8), 1612-1619.

Alrabai, F. (2014). A model of foreign language anxiety in the Saudi EFL context. English Language Teaching, 7(7), 82.

Al-Sabbah, S. S. (2016). The Effect of Study Habits on English Language Achievement. Arab World English Journal, 7(4), 238-257.

Al-Sheikh, S. A., \& Abd Alrhaheem, A. R. (1993). Learning and study habits and their 
relation to achievement, intelligence and learning motivation. Papers of Educational Researches Center, Qatar University.

Al-Shennawi, A. A. (1998). The relationship of study habits and attitudes towards study with Educational Courses achievement among Faculty of Education students in Zagazig University. Cairo: Dar Al-Nahda Al-Arabia.

Al-Shlawi, B. A. (2016). Study habits and its relationship with achievement and metacognition skills in a sample of Taif University students (MA thesis, Dal Al-Mnazoma).

Bender, D. S. (2001). Effects of study skills programs on the academic behaviors of college students. Journal of College Reading and Learning, 31(2), 209-216.

Chan, M., Yum, J., Fan, R., Jegede, O., \& Taplin, M. (1999). A comparison of the study habits and preferences of high achieving and low achieving Open University students. Paper Presented at the $13^{\text {th }}$ Annual Conference of the Asian Association of Open Universities, Beijing $14^{\text {th }}-17$ th October.

Dennis, H. C. (2010). Study Skills Inventory. Formerly of Central Piedmont Community College, Charlotte, North Carolina. Retrieved from https://bluegrass.kctcs.edu/.../study_ skills_inventory.ash

Elyas, T., \& Badawood, O. (2017). English language educational policy in Saudi Arabia post $21^{\text {st }}$ century: Enacted curriculum identity and modernization: A critical discourse analysis approach. FIRE: Forum for International Research in Education, 3(3), 78. Retrieved from http://preserve.lehigh.edu/fire/vol3/iss3/3

Essa, A. A. (2000). Study habits and their relation to achievement and level of ambition and anxiety among high school students in Omdurman in Khartoum (Unpublished Ph.D. Diss., Faculty of Arts, Omdurman Islamic University).

Fatim, L. M. (1989). The relation between study habits and achievement among the students of University College of Bahrain. The Arabic Journal of Humanities, 9(36), 113-137.

Fredrick, K. C. (1998). The relationship between study skills training and student grades and achievement test scores. Diss. Abst. Inter., 59 (7-A), 2464.

Ghanimat, K. A., \& Alimat, A. R. (2012). Impact of utilizing study skills-based counseling program in improving achievement and motivation. Journal of the Islamic University for Educational and Psychological Studies, 20(2), 23-51.

Ghoneim, I. (2005). The effectiveness of drawing systemic approach-based educational program in engineering thinking and the retention of learning impact among the students of the Faculty of Industrial Education. Faculty of Education Journal, 21(2), 249-285.

Hacker, N. (1999). Parental involvement in student's acquisition and application of study skills in elementary school homework activities. Diss Abst. Inter., 60(5-A), 14-56.

Huang, S. C. (2018). Language Learning Strategies in Context. Language Learning Journal, $46(5), 647-659$. 
Hussein, M. H. (2007). The relative contribution of study skills and test anxiety in predicting the academic performance of the primary stage students. Egyptian Journal of Psychological Studies, 17(54), 284-333.

Ickes, C., \& Fraas, J. (1990). Study skills differences among high-risk college freshman. Paper Presented at the Annual Meeting of the Mid-Western Educational Research Association (12th, Chicago, IL, October 17-20).

Jegede, J., Jegede, R., \& Ugodulunwa, C. (1997). Effects of achievement motivation and study habits on Nigerian secondary school student's academic performance. Journal of Psychology, 131(5), 523-529.

Khan, I. (2011). Learning difficulties in English: Diagnosis and pedagogy in Saudi Arabia. Educational Research, 2(7), 1248-1257.

Lin, G., \& Mckeachie, W. (2003). Aptitude anxiety, study habits and academic achievement. Journal of College Students Personnel, 27, 306-309.

Mitchel, B., \& Alfuraih, A. (2017). English Language Teaching in the Kingdom of Saudi Arabia: Past, Present and Beyond. Mediterranean Journal of Social Sciences, 8(2), 317-325.

Musch, J., \& Broder, A. (1999). Test anxiety versus academic skills: A comparison of two alternative models for predicting performance in a statistics exam. British Educational Psychological, 69(1), 105-116.

Nabih, B. M. (1990). Study habits and their relation to achievement among university students. Faculty of Education Journal, 14(2), 181-219.

Oakerson, P. (1993). Teaching and assessing study skills: A classroom study. Paper Presented at The Annual Meeting of the Midwest Association of Teachers of Educational Psychology (Anderson, IN, October).

Okasha, M. (1999). Mental Hygiene. Alexandria: Al-Gomhoria Press.

Oluwatimilehin, J. T. B., \& Owoyele, J. W. (2012). Study habits and academic achievement in core subjects among junior secondary school students in Ondo State, Nigeria. Bulgarian Journal of Science and Education Policy, 6(1).

Raaheim A. (2003). Can students be taught to study? An evaluation of a study skill program directed at first year students at The University of Bergen. Journal of Educational Research. 28(1), 9-15.

Rahman, M., \& Alhaisoni, E. (2013). Teaching English in Saudi Arabia: Prospects and challenges. Academic Research International, 4(1), 112.

Rizk, M. A. (2004). Modern Approaches in investigating study skills. Journal of Education and Psychology, 13(2), 1-28.

Sedat, Y. (2006). Undergraduate students' resistance to Study Skills Course. College Student Journal, 40(1), 158-165. 


\section{Macrothink}

Sirohi, V. (2004). A Study of underachievement in relation to study habits and attitudes. Journal of Indian Education, 19(1), 14-19.

Suliman, S. M. (1988). Study habits and its relationship with excellence. Papers of Psychology $4^{\text {th }}$ Conference in Egypt. Center of Human Resources and Information, Giza.

Turkistani, W. A. (2015). The impact of study skills-based program on achievement and test anxiety among high school students in Taif (Unpublished MA thesis, Faculty of Education, Taif University).

Wafi, A. (2010). Life skills and their relation to multiple intelligence among high stage students in Gaza Strip (MA thesis, Islamic University, Gaza, Palestine).

Wernersbach, B. (2011). The impact of study skills courses on academic self-efficacy in college freshmen (MA Thesis, Utah State University, Logan, Utah, USA).

Zidan, A., \& Ibrahim, A. (1990). The relationship of study habits, attitudes towards study, and general study attitude with achievement and general mental ability. Zagaziq Faculty of Education Journal, 2, 213-261.

\section{Copyright Disclaimer}

Copyright for this article is retained by the author(s), with first publication rights granted to the journal.

This is an open-access article distributed under the terms and conditions of the Creative Commons Attribution license (http://creativecommons.org/licenses/by/3.0/). 